\title{
The Nutrient Content of English Prison Diets in 1944
}

\author{
By MAGNUS PYKE, Scientific Adviser's Division, Ministry of Food, London
}

(Received I3 March I947)

The inmates of prisons are restricted to a rigid diet which they are unable to vary or supplement, and upon which they may have to subsist for long periods of time. It is therefore of cardinal importance that the diet scales provided for them should be nutritionally adequate in every respect. There are numerous historical reports of malnutrition occurring in prisons. Between 1939 and 1944 it was found necessary to introduce a number of changes into the diets provided in prisons in England in order to maintain conformity with civilian rations. The present study was consequently planned and executed in 1944 in order to assess the nutritional adequacy of the diets then in force.

\section{EXPERIMENTAL}

The investigation was carried out in November and December and was designed to include the diets provided in the principal different types of prisons in England. Consequently a large prison for men in London was studied, a smaller prison in the country and a convict prison. The diets of women in a big London prison and at a convict prison were analysed and the diets of adolescent boys were examined in a prison, a 'closed' Borstal institution and an 'open' Borstal institution. Similarly, the food consumption of adolescent Borstal girls was also investigated. A 'closed' Borstal institution is one in which young offenders are confined in a prison building and are locked into cells at night. In an 'open' Borstal institution the buildings are similar to those of a hutted camp, the inmates sleep in dormitories and much of their work is done in the open air.

The meals provided in prison usually consist of breakfast at about $7.30 \mathrm{a} . \mathrm{m}$. composed of porridge, a ' $\mathrm{knob}$ ' of bread, a standard pat of margarine and a pint of tea; dinner at noon consisting of a different set dish for each day of the week, say stew and baked potatoes served in an individual prison tin with duff in a second metal container fitting on to the top of the first; and supper at about 5 p.m. comprising bread, margarine and cocoa with the occasional addition of cheese. In the majority of cases prisoners eat their meals locked up in their individual cells. In Borstal institutions meals are usually eaten in a mess hall and an additional supper of bread and cocoa given at 8 p.m.

The general principle of prison catering is that every inmate shall receive the same amount to eat. Only where a job is exceptionally hard, for example, stoking the prison boilers, or when the doctor sees fit, is additional food provided.

The nutritive value of the ration scales in force at the end of 1944 has been calculated in Table I. The food tables used were those employed by the Ministry of Food (1945). 
Table $\mathrm{x}$. The nutritive value of prisoners' ration scales

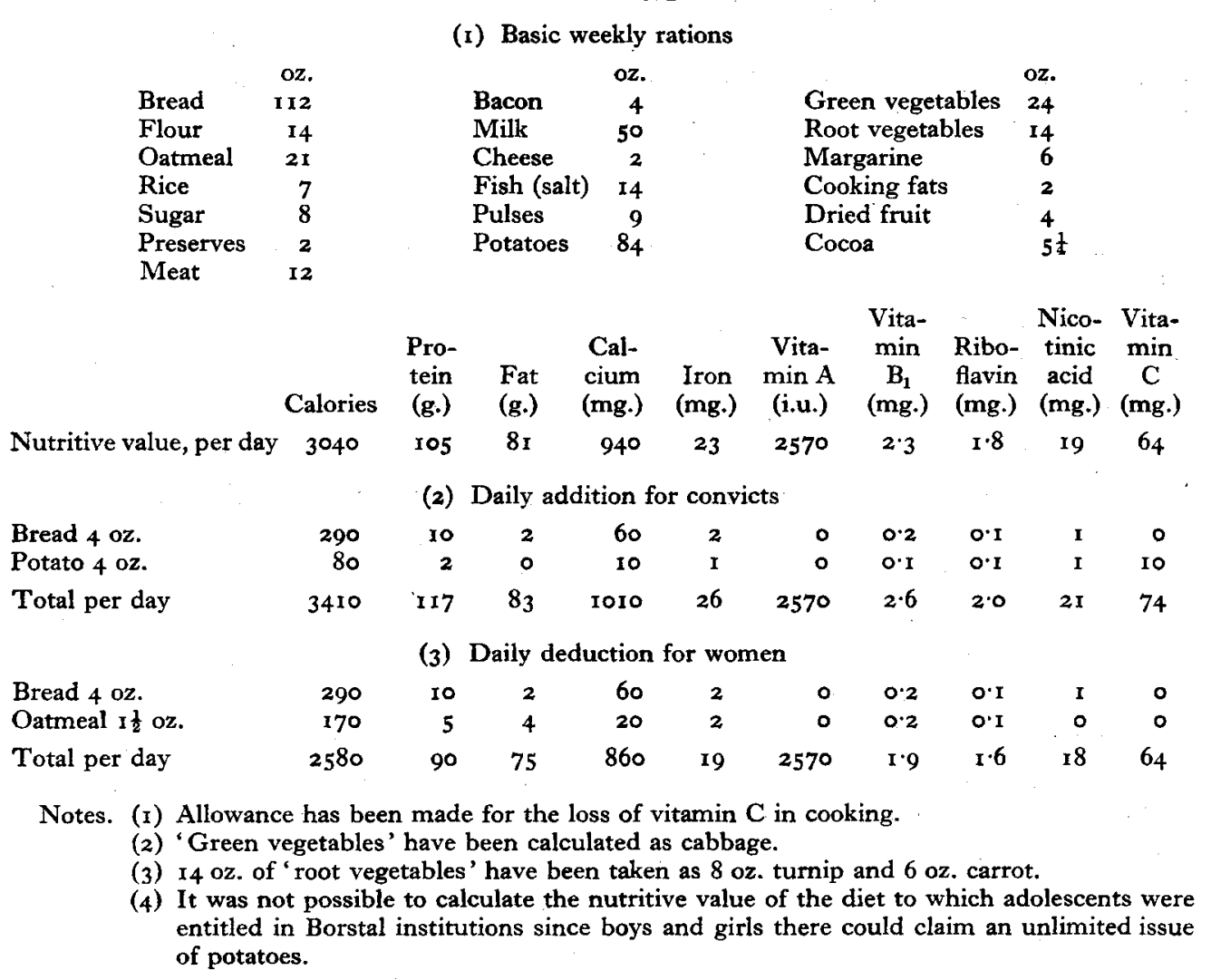

\section{METHODS}

It is traditional prison practice for meals to be weighed out into individual tins from which they are eaten. In order to obtain a representative sample for analysis, six to ten servings of each meal were diverted from a like number of prisoners, the weight of each ingredient recorded, and an amount equal to the arithmetical mean collected in a large jar. When foodstuffs likely to contain vitamin $\mathrm{C}$ were encountered additional duplicate samples of approx. ro g. were taken and put into weighed, screw-capped, glass bottles containing $20 \mathrm{ml}$. of $2 \%$ oxalic acid. In order to make an allowance for food issued, but not eaten, six to ten prisoners, chosen as being broadly representative of the group under investigation, were selected and the average amounts left uneaten by these individuals were deducted from the samples of food taken for examination. In general, the amount of food refused was very small. Collections were made in this manner for 7 consecutive days.

The composite samples representing the daily food consumption of an individual prisoner were thoroughly mixed by passing the whole twice through a mincer and were then dried in trays in an air-bath at a temperature of $90-100^{\circ}$. The total amount of air-dried material was then very thoroughly ground with a pestle and mortar and sent to the Government Laboratory where analysis of protein, fat, mineral matter, 
carbohydrate (by difference), calories (by calculation using the Rubner factors), calcium and iron were carried out by the methods detailed in the Memorandum on Hospital Diet published by King Edward's Hospital Fund for London (1943). The use of a mincer on the wet material prior to the determination of iron was thought to be justifiable, in spite of the possibility of slight contamination with this metal owing to the much larger amounts derived from prison utensils and particularly from the tins in which the meals were served.

Vitamin $\mathrm{C}$ was determined in the special samples taken for the purpose by titration with 2:6-dichlorophenolindophenol (Ponting, 1943). Precautions were taken to avoid misleading results due to interfering substances in, for example, gravy browning (Levy, 1943).

Tea and cocoa, which formed a part of breakfast and supper respectively, were, for technical reasons, not collected with the day's diet. A standard issue of both these fluids was, however, taken separately, evaporated to dryness and analysed.

Nicotinic acid was determined microbiologically on the mixed daily samples before drying and a few estimations of riboflavin were also made. Values for vitamin A, vitamin $B_{1}$ and riboflavin have been calculated. These calculated figures are at best only approximations. For example, vitamin $A$ in the prison diet is derived not only from margarine, milk and cheese, but also from carrot and cabbage and, whereas an exact amount of the first three items is portioned out to each prisoner and can, in the case of cheese and margarine at least, be weighed precisely, carrot and cabbage may be broken up in stews and other dishes and may not be distribufed equally. Furthermore, the amount of vitamin $A$ in vegetables may vary very widely. For example, the cabbage used at the first prison studied was very pale in colour, suggesting that the amount of vitamin A-active material in it was low. Allowance for this has been made in the calculation. Similarly, the assessment of vitamin $B_{1}$ in vegetable soup or 'sea pie' can only be approximate since investigation of losses occurring in making these dishes under prison conditions was not made. Nevertheless, the calculated values give some indication of the proportions of the respective nutrients likely to have been present.

\section{RESULTS}

The average nutritive values of the diets at each of these types of institutions, studied in each case over a continuous period of a week, are shown in Table 2. The figures for the requirements of each group are the 'restricted allowances' of the Food and Nutrition Board of the U.S.A. National Research Council (1945).

\section{DISCUSSION}

The energy requirements of the inmates in prisons are not very great. The total day's requirement includes the following components: $5 \frac{1}{2} \mathrm{hr}$. 'domestic' activity representing the expenditure of, say, I6 5 Cal., I hr. 'exercise', say, r ro Cal., $5 \frac{1}{2} \mathrm{hr}$. work varying in demands from, say, 50 to $90 \mathrm{Cal} . / \mathrm{hr}$., and thus totalling $275-495 \mathrm{Cal}$., and the needs for basal metabolism and specific dynamic action, say, 1630 Cal. The total needs therefore range from 2180 to 2400 Cal. daily (Orr \& Leitch, 1937-8). The above 
assessment applies to the average male prisoner who is locked up at about 4.30 p.m. The activity of female prisoners is approximately the same as that of the males and their requirements therefore range from 2000 to 2220 Cal. These estimates show that the adult prisoners were obtaining an adequate total amount of food from their rations.

Table 2. The nutritive value found for the average daily diets eaten by prisoners in a number of different types of institutions in England in 1944

The figures for requirements are the 'restricted allowances' of the Food and Nutrition Board of the U.S.A. National Research Council (1945) except those for the calorie needs of men and nonpregnant women and those for fat.

The figures in brackets have been calculated from food tables.

\begin{tabular}{|c|c|c|c|c|c|c|c|c|c|c|}
\hline Type of institution & Calories & $\begin{array}{l}\text { Pro- } \\
\text { tein } \\
\text { (g.) }\end{array}$ & $\begin{array}{l}\text { Fat } \\
\text { (g.) }\end{array}$ & $\begin{array}{c}\text { Cal- } \\
\text { cium } \\
\text { (mg.) }\end{array}$ & $\begin{array}{c}\text { Iron } \\
\text { (mg.) }\end{array}$ & $\begin{array}{c}\text { Vita- } \\
\text { min } \\
\text { A } \\
\text { (i.u.) }\end{array}$ & $\begin{array}{c}\text { Vita- } \\
\text { min } \\
\mathbf{B}_{1} \\
(\mathrm{mg} .)\end{array}$ & $\begin{array}{l}\text { Ribo- } \\
\text { flavin } \\
\text { (mg.) }\end{array}$ & $\begin{array}{c}\text { Nico- } \\
\text { tinic } \\
\text { acid } \\
\text { (mg.) }\end{array}$ & $\begin{array}{c}\text { Vita- } \\
\text { min } \\
\mathrm{C} \\
(\mathrm{mg} .\end{array}$ \\
\hline
\end{tabular}

I. Men:

\begin{tabular}{|c|c|c|c|c|c|c|c|c|c|}
\hline $\begin{array}{l}\text { (I) Large London } \\
\text { prison }\end{array}$ & 2450 & 84 & 50 & $84^{\circ}$ & 47 & $\left(355^{\circ}\right)$ & $(I \cdot 6)$ & $(I \cdot 2)$ & 16 \\
\hline $\begin{array}{l}\text { (2) Small country } \\
\text { prison }\end{array}$ & 2330 & 85 & 49 & $114^{\circ}$ & 28 & $(2170)$ & $(\mathrm{I} \cdot 8)$ & $(1 \cdot 5)$ & I8 \\
\hline 3) Convict prison & 2590 & 94 & 43 & 860 & 43 & (2010) & $(2 \cdot 1)$ & $(\mathrm{I} \cdot 6)$ & 17 \\
\hline Requirement & 2400 & 70 & 86 & 560 & 8 & 3500 & 0.8 & $I \cdot 0$ & 8 \\
\hline
\end{tabular}

II. 'Normal' women:

(I) London prison

(2) Convict prison

$\begin{array}{lll}2120 & 72 & 50 \\ 2020 & 74 & 48\end{array}$

$\begin{array}{rrccccc}830 & 22 & (4270) & (I \cdot 6) & (\mathrm{x} \cdot 3) & \mathrm{r} 7 & 37 \\ 670 & 29 & (2070) & (1 \cdot 5) & (1 \cdot 4) & 14 & 17 \\ 560 & 8 & 3500 & 0.8 & 1 \cdot 0 & 8 & 49\end{array}$

III. Pregnant women:

(I) London prison

(2) Convict prison

\section{5}

$27 \times 5$

$\begin{array}{ll}110 & 76 \\ 103 & 84\end{array}$

$1630 \quad 27$.

Requirement

2500

8590

$1500 \quad I 5$

$\begin{array}{lllll}(7880) & (2 \cdot 3) & (2 \cdot 4) & 20 & 64\end{array}$

$\begin{array}{lllll}(5570) & (1.7) & (2.4) & 14 & 40\end{array}$

IV. Lactating women:

(I) London prison

(2) Convict prison

Requirement

2715
2700
3000

$\begin{array}{lr}\text { IOI } & 75 \\ \text { IOI } & 82 \\ \text { IOO } & 108\end{array}$

$\begin{array}{ll}1570 & 25 \\ 1655 & 29 \\ 2000 & 15\end{array}$

(7880) (2:1) (2:3)

$\begin{array}{lll}(5510) & (\mathrm{x} \cdot 7) & (2 \cdot 4)\end{array}$

$2 \cdot 0$

$3.0-23$

V. Adolescent boys :

(I) 'Closed' Borstal

(2) 'Open' Borstal

(3) Prison

$$
3270
$$

$\begin{array}{rrr}114 & 53 & 1200 \\ 116 & 58 & 1390 \\ 83 & 54 & 870 \\ 100 & 137 & 1400\end{array}$

$\begin{array}{rccccr}-41 & (2400) & (2 \cdot 5) & (1 \cdot 8) & 24 & 55 \\ 53 & (3470) & (2 \cdot 6) & (1 \cdot 9) & 27 & 52 \\ 43 & (3550) & (1 \cdot 5) & (1 \cdot 3) & 16 & 16 \\ 15 & 6000 & 1 \cdot 8 & 2 \cdot 5 & 18 & 100\end{array}$

VI. Adolescent girls :

$\begin{array}{lcccccccccc}\text { (1) Borstal } & 2245 & 75 & 42 & 665 & 16 & (2000) & (1 \cdot 6) & (1 \cdot 5) & 17 & 23 \\ \text { (2) Prison } & 2120 & 72 & 50 & 830 & 22 & (4270) & (1 \cdot 6) & (1 \cdot 3) & 17 & 37 \\ \quad \text { Requirement } & 2400 & 75 & 86 & 1000 & 15 & 5000 & 1 \cdot 2 & 1 \cdot 8 & 12 & 80\end{array}$

The adolescent boys in Borstal institutions lived a vigorous outdoor life, and their Calorie requirements were almost certainly fully equal to the $3^{800}$ suggested by the U.S.A. National Research Council. The observation that these youths were always ravenously hungry confirms the suggestion inherent in the figures given in Table 2 
that their food intake was insufficient for their needs. The calorie consumption of adolescent boys in prison, in contrast to those in Borstal institutions, is of interest, since the boys in prison lived a confined life broadly similar to that of the adult prisoners. The suggested requirement of $3800 \mathrm{Cal}$. cannot therefore be applied directly to this group.

When the over-all composition of the diet eaten by male prisoners is considered it would appear to be adequate so far as protein, calcium, iron and B vitamins are concerned. The intake of iron, indeed, is substantially larger than the requirements. The high iron content of the diet is probably derived from the metal vessels in which it is served and which are often rusty and battered. The vitamin A in the diet is not in all cases adequate. Where the amounts present are insufficient this is due to an inadequate supply of carrots and green vegetables during the week of study. Since in the tables used to calculate vitamin A an adjustment had been made to allow for the reduced availability of carotene in vegetable foods and since no such adjustment was made by the U.S.A. National Research Council in estimating requirements, the figures given in the table are not strictly comparable. However, the League of Nations (r937) assessment of the vitamin $A$ requirements of adults which makes allowance for the possible variation in the accepted values taken for foods, is $2000-4000$ i.u. daily. It is, therefore, not unreasonable to compare the assumed consumption shown in Table 2 with an estimated requirement of 3500 i.u. The supply of vitamin $C$, while less than that recommended for optimum nutrition, is probably sufficient to prevent frank ill-health. The fluctuation between the different prisons is due to different methods of cooking and differing proportions of vegetables. The diet samples from which these analyses of vitamin C were made were collected in November and December 1944.

The figure suggested for the fat requirement is the amount needed to provide onethird of the day's calories. Although this figure cannot claim to represent a physiological necessity, the very marked shortage of fat in the diet was accompanied by a marked degree of unpalatability and bulkiness.

The shortcomings in the nutritive value of the diets in women's prisons were substantially similar to those of the men. The food provided for pregnant and lactating women was modified to meet their special nutritional needs by the addition of supplements of milk, cod-liver oil and orange juice. The vitamin $\mathrm{C}$ content of the latter was, as in the case of other foods, determined by analysis. Although the diets for these two groups appeared to be deficient in calcium and vitamin $\mathrm{C}$ when compared with the high targets of the U.S.A. National Research Council, the quality of the diets was in general satisfactory. The calorific value of the diet for nursing mothers was less than the estimated requirement.

The life of the adolescent boys in Borstal institutions and particularly in the 'open' Borstal, was very rigorous and there seems little doubt that the calorific value of the diets was insufficient. In all cases the boys exhibited a voracious hunger. In these diets the marked shortage of fat was important. At the time of the survey a substantial proportion of the calories was made up by potatoes which were added to take the place of a proportion of the normal bread ration. Thus, the bulky nature of the diet was even further accentuated. The situation was radically different for the boys 
in prisons since, as has already been remarked, the energy expenditure of this group was markedly restricted.

The diets of the Borstal girls were adequate in protein, iron, vitamin $B_{1}$ and nicotinic acid. The low proportion of fat probably encouraged the under-consumption of calories. However, although some of the girls claimed to be hungry at all times this was not the case with the entire group.

It can be seen that there was a substantial margin between the nutritive value of the rations officially issued to the different categories of prisoners and the composition of the diets eaten. Part of this difference can be attributed to losses occurring during the preparation of the food, although part is probably due to other reasons.

\section{SUMMARY}

r. A detailed nutritional study was carried out in 1944 of the diets eaten by prisoners at a large London prison for men, at a small country prison and at a convict prison. The diets were also studied at a large London prison for women and at a convict prison for women. Similarly a 'closed' boys' Borstal, a 'closed' girls' Borstal and an 'open' boys' Borstal were also investigated.

2. The nutritive value of the diets was determined by collecting for 7 consecutive days a number of examples of all the meals actually given to a group of inmates. Throughout the week each example of every meal was weighed and an average day's diet collected for each of the 7 days. These seven average diets were analysed in the laboratory for protein, fat, calcium, iron, nicotinic acid and vitamin $\mathrm{C}$. The calorie content was derived from the analytical figures. Vitamin $A$, vitamin $B_{1}$ and riboflavin were estimated by calculation.

3. The amounts of calories, protein, calcium, iron, vitamin $A$, vitamin $B_{1}$, riboflavin and nicotinic acid were, with some exceptions, found to be adequate. Many of the diets showed a shortage of vitamin C. A shortage of fat rendered all the diets bulky and thus tended to reduce their acceptability. An occasional deficiency of vitamin A was found.

4. The general composition of Borstal diets was found to be not dissimilar to those provided for adult prisoners. The amount of food supplied to Borstal boys was, as measured by calories, to some extent insufficient and the general shortage of fat was, therefore, more serious in its effect than in the case of adult prisoners. Owing to the higher physiological requirements of adolescents there was a shortage of vitamin $\mathrm{A}$ in their diets.

This investigation was carried out with the co-operation and support of the Prison Commissioners who have already taken steps to remedy many of the deficiencies shown to exist in the diets studied. Acknowledgment must also be made to the Government Laboratory where the analysis of proximate constituents of the diets was carried out and to the Research Laboratories, Vitamins Ltd. for determinations of vitamin C and nicotinic acid. Finally, I wish to acknowledge the advice and encouragement of Sir Jack Drummond, F.R.S. 


\section{REFERENCES}

King Edward's Hospital Fund for London (1943). Memorandum on Hospital Diet. London: Geo. Barber and Son, Ltd.

League of Nations Health Organization. Technical Committee on Nutrition (1937). Bull. Hlth Org. L.o.N. 7, 472.

Levy, L. F. (1943). Nature, Lond., 152, 693.

Ministry of Food (1945). Manual of Nutrition. London: H.M.S.O.

Orr, J. B. \& Leitch, I. (1937-8). Nutr. Abstr. Rev. 7, 509.

Ponting, J. D. (1943). Industr. Engng Chem. (Anal. ed.), I5, 389.

U.S.A. National Research Council. Food and Nutrition Board (1945). Rep. nat. Res. Coun., Wash., no. 122. 